\title{
Effect of Hemoglobin Levels on Cardiovascular Outcomes in Patients with Isolated Systolic Hypertension and Left Ventricular Hypertrophy (From the LIFE Study)
}

Marianne L. Smebye ${ }^{\mathrm{a}}$, Emil K. Iversen ${ }^{\mathrm{a}}$, Aud Høieggen, MD ${ }^{\mathrm{a}}$, Arnljot Flaa, MD ${ }^{\mathrm{a}}$, Ingrid Os, MD ${ }^{\mathrm{a}}$, Sverre E. Kjeldsen, MD, $\mathrm{PhD}^{\mathrm{a}, \mathrm{b}}$, Michael Hecht Olsen, $\mathrm{MD}, \mathrm{PhD}^{\mathrm{c}}$, Arghya Chattopadhyay, $\mathrm{PhD}^{\mathrm{d}}$, Darcy A. Hille, MS, EMBA' ${ }^{\mathrm{d}}$, Paulette A. Lyle, BS ${ }^{\mathrm{d}}$, Richard B. Devereux, $\mathrm{MD}^{\mathrm{e}}$, Björn Dahlöf, MD, PhD ${ }^{\mathrm{f}}$.

From ${ }^{\mathrm{a}}$ Departments of Nephrology and Cardiology, University of Oslo Ullevaal Hospital, Oslo, Norway; ${ }^{b}$ Department of Cardiovascular Medicine, University of Michigan, Ann Arbor, Michigan, USA;

${ }^{\mathrm{c}}$ Glostrup University Hospital, Glostrup, Denmark; ${ }^{\mathrm{d}}$ Merck Research Laboratories, Upper Gwynedd, Pennsylvania, USA; ${ }^{\circledR}$ Department of Cardiology, Weill Medical Center of Cornell University, New York, New York, USA; and ${ }^{\mathrm{f} D e p a r t m e n t ~ o f ~ M e d i c i n e, ~ S a h l g r e n s k a ~ U n i v e r s i t y ~ H o s p i t a l / O ̈ s t r a, ~ G o ̈ t e b o r g, ~}$ Sweden

The LIFE study was sponsored by Merck \& Co., Inc., Whitehouse Station, New Jersey.

Correspondence to Aud Høieggen, Department of Nephrology, University of Oslo Ullevaal Hospital, N0407, Oslo, Norway. Telephone: 472211 9101. Fax: 472211 9181. E-mail: aud.hoieggen@ioks.uio.no

Running title: LIFE hemoglobin and ISH 


\begin{abstract}
The optimal hemoglobin level in patients with hypertension or heart failure is not yet defined. The aim of the present investigation was to examine the relation of hemoglobin with cardiovascular outcomes in high-risk patients with isolated systolic hypertension (ISH) and left ventricular hypertrophy (LVH). In 1326 patients with ISH in the Losartan Intervention For Endpoint reduction in hypertension (LIFE) study, hemoglobin and cardiovascular outcomes were examined using Cox proportional hazard models. Baseline hemoglobin was negatively related to the rate of cardiovascular death (hazard ratio 0.81 [95\% CI $0.67-0.98]$ per $1 \mathrm{~g} / \mathrm{dL}, \mathrm{p}=0.032$ ) after adjusting for baseline Framingham risk score (FRS), LVH, treatment, and estimated glomerular filtration rate (eGFR). Hemoglobin decreased slightly during the study and the decline was more pronounced in the losartan group $(13.9 \pm 1.3 \mathrm{~g} / \mathrm{dL}$ to $13.6 \pm 1.4 \mathrm{~g} / \mathrm{dL})$ than in the atenolol group $(13.9 \pm 1.2 \mathrm{~g} / \mathrm{dL}$ to $13.8 \pm 1.4 \mathrm{~g} / \mathrm{dL})$. Hemoglobin as a time-varying covariate was negatively associated with the rate of cardiovascular death (hazard ratio 0.75 [0.63-0.90], p < 0.001) and stroke (hazard ratio 0.84 [0.72-0.99], p=0.040), after adjusting for baseline FRS, LVH, treatment, and eGFR. In conclusion, in this high-risk population with ISH and LVH, lower hemoglobin at baseline was associated with higher probability of cardiovascular death, and fall in hemoglobin over time was associated with higher probability of cardiovascular death or stroke and this effect was attenuated by treatment with losartan.
\end{abstract}

Key words: cardiovascular risk, hemoglobin, hypertension, isolated systolic hypertension, left ventricular hypertrophy 


\section{Introduction}

Hemoglobin can effect peripheral vascular resistance in 2 ways according to the PoiseuilleHagen equation: primarily by influencing the viscosity of blood, ${ }^{1}$ and secondarily by affecting the caliber of peripheral arterioles. ${ }^{2}$ High hemoglobin levels have been related to increased cardiovascular risk ${ }^{3}$ and may induce left ventricular hypertrophy (LVH) in patients with hypertension. ${ }^{4}$ On the other hand, low hemoglobin levels are also associated with cardiovascular risk. The potentially harmful effect of anemia has been shown in the general population ${ }^{5}$ and in patients with heart failure. ${ }^{6}$ Little is known about hemoglobin levels and cardiovascular outcome in the hypertensive population. In the Losartan Intervention For Endpoint reduction in hypertension (LIFE) study, the effects of losartan were compared with atenolol in the context of comparable blood-pressure lowering. ${ }^{7}$ The aim of the present study was to investigate the relation between hemoglobin and cardiovascular outcomes in this prespecified group of wellcharacterized hypertensive subjects with high cardiovascular risk.

\section{Methods}

Study design and organization: The LIFE study was a prospective, multinational, multicenter, double-blind, double-dummy, randomized, active-controlled, parallel-group study. The primary objective was to evaluate the long-term effects of losartan- compared with atenololbased antihypertensive therapy in patients with hypertension and electrocardiographically (ECG) documented LVH on the incidence of cardiovascular morbidity and mortality. The LIFE study design, organization, clinical measures, endpoint definitions, basis for choice of comparative agents, statistical power calculations, recruitment details, baseline characteristics, 1-year followup, and primary results have been published. ${ }^{7-11}$ Hemoglobin levels were obtained at baseline 
immediately prior to randomization and at annual clinic visits. The trial protocol was approved by local ethics committees and performed in accordance with the Declaration of Helsinki. The study was overseen by an independent data and safety monitoring board. All participants gave written informed consent.

Target population and treatment schedule: Persons aged 55 to 80 years with previously treated or untreated hypertension and ECG evidence of LVH were enrolled in the LIFE study. Those with secondary hypertension; myocardial infarction or stroke within the previous 6 months; angina pectoris requiring treatment with $\beta$-blockers or calcium antagonists; active heart failure or known left ventricular ejection fraction $40 \%$; or a disorder that, according to the treating physician's opinion, required treatment with open-label study medication or related drugs were excluded. Also excluded were patients with serum creatinine $>1.8 \mathrm{mg} / \mathrm{dL}$ (160 $\mathrm{mol} / \mathrm{L})$, a solitary kidney, or kidney transplant. Eligible persons were randomly assigned to losartan- or atenolol-based regimens after 1 or 2 weeks of placebo if trough sitting blood pressures were 160-200 $\mathrm{mm} \mathrm{Hg}$ systolic, $95-115 \mathrm{~mm} \mathrm{Hg}$ diastolic, or both. In this analysis, the patients had trough sitting blood pressure between 160-200 mm Hg systolic with diastolic pressure $<90 \mathrm{~mm} \mathrm{Hg}{ }^{12}$ From July 6, 1995, through May 2, 1997, a total of 1326 patients with ISH were randomized to treatment in the LIFE study. ${ }^{12}$ Patients were followed for 4 or more years with regular visits and upward titration of medication to reach a goal systolic blood pressure of $<140 \mathrm{~mm} \mathrm{Hg}$. Only 2 patients $(0.2 \%)$ with ISH were lost to follow-up.

ECG coding and LVH criteria: All ECGs were evaluated at a central core reading center for LVH criteria and Minnesota Codes. ECG-LVH was measured using gender-adjusted Cornell product criteria $(\mathrm{RaVL}+\mathrm{SV} 3[+6 \mathrm{~mm}$ in women] $\mathrm{x}$ QRS duration $)>2440 \mathrm{~mm} \bullet \mathrm{msec}$ or Sokolow-Lyon voltage $\left(\mathrm{S}_{\mathrm{V} 1}+\mathrm{RV}_{5 / 6}\right)>38 \mathrm{~mm} .{ }^{8,13-15}$ 
Outcome measures: The primary endpoint was a composite of cardiovascular death, fatal or non-fatal stroke, and fatal or non-fatal myocardial infarction. Other prespecified outcome measures were components of the primary composite endpoint, total mortality, hospitalization for angina pectoris, hospitalization for heart failure, coronary or peripheral revascularization procedures, resuscitated cardiac arrest, and new-onset diabetes mellitus. ${ }^{7}$ Routine laboratory tests were performed in 2 central laboratories. The study ran its full course and endpoint follow-up was stopped on September 16, 2001.

Statistical methods: The prespecified data analysis plan for the LIFE study highlighted ISH as being of particular interest and indicated that all endpoint analyses were to be performed in this subgroup. The study of the effect of hemoglobin in the ISH population is post hoc. Hemoglobin level is expressed as mean (standard deviation). All cardiovascular endpoints and blood pressures were analyzed using the intention-to-treat approach. Participants who experienced $>1$ endpoint were counted as having an event in all relevant endpoint analyses; however, only the first event in a specific category was counted in individual analyses. The associations between hemoglobin and cardiovascular outcomes were examined using Cox proportional hazard models using hemoglobin as a continuous variable or stratified by hemoglobin quintiles. The models were adjusted for Framingham risk score, LVH, treatment, and estimated glomerular filtration rate (eGFR) calculated by using the abbreviated Modification of Diet in Renal Disease study (MDRD) equation. ${ }^{16}$ The time-varying hemoglobin analyses included all of the hemoglobin values that were observed before an endpoint and the time between those values as covariates in the Cox regression models.

\section{Results}


Patient characteristics: Of the 9193 patients participating in the LIFE study, 1326 fulfilled the criteria necessary for inclusion in this analysis. Patients did not have serious renal dysfunction (baseline mean serum creatinine $0.98+0.23 \mathrm{mg} / \mathrm{dL}[86.9+20.2 \mu \mathrm{mol} / \mathrm{L}]$ ). Compared with the overall LIFE population, patients in the LIFE ISH subgroup were older, had lower diastolic blood pressure, and higher prevalences of coronary heart disease, cerebrovascular disease, peripheral vascular disease, atrial fibrillation, and diabetes at baseline. The mean age was $70 \pm 6$ years; $60 \%$ of patients were women; $92 \%$ were white and $6 \%$ black; $18 \%$ had diabetes; and mean blood pressure was $174 \pm 11 / 83 \pm 6 \mathrm{~mm} \mathrm{Hg}$. When anemia was defined as hemoglobin $<13.8 \mathrm{~g} / \mathrm{dL}$ for males or $<12.1 \mathrm{~g} / \mathrm{dL}$ for females, the distribution of baseline anemia was significantly different $(\mathrm{p}<0.0001)$ between males and females: $23.6 \%$ (111 out of 470$)$ of males and 7.6\% (55 out of 722) of females had anemia at baseline. Additional baseline characteristics for the ISH subgroup are presented in Table 1, and are similar in the losartan and atenolol groups. Cardiovascular events and treatment effects in the ISH subgroup of LIFE have been published. ${ }^{12}$ The treatment benefits of losartan were more pronounced for the primary composite endpoint, cardiovascular death, and stroke than for myocardial infarction.

Hemoglobin and endpoints: Hemoglobin decreased in both treatment groups during the study, more so in the losartan group $(13.9 \pm 1.3 \mathrm{~g} / \mathrm{dL}$ to $13.6 \pm 1.4 \mathrm{~g} / \mathrm{dL})$ than in the atenolol group (13.9 $\pm 1.2 \mathrm{~g} / \mathrm{dL}$ to $13.8 \pm 1.4 \mathrm{~g} / \mathrm{dL}$ ) (Figure 1$)$.

Baseline hemoglobin was negatively related to the rate of cardiovascular death (hazard ratio 0.81 [95\% CI 0.67-0.98] per $1 \mathrm{~g} / \mathrm{dL}, \mathrm{p}=0.032$ ) after adjusting for baseline Framingham risk score, treatment LVH, and eGFR. Results were also examined by quintiles of baseline hemoglobin level, where the reference group was the lowest quintile of hemoglobin ( $12.9 \mathrm{~g} / \mathrm{dL}$ ) (Figure 2). There were negative relations between hemoglobin levels at baseline over the range of levels observed in this study and the 
primary composite endpoint, cardiovascular death, and stroke, but there was a minimally higher rate of myocardial infarction in the highest hemoglobin quintile (Figure 2). Hemoglobin as a time-varying covariate was negatively associated with the rate of cardiovascular death (hazard ratio 0.75 [0.63-0.90], $\mathrm{p}<0.001$ ) and stroke (hazard ratio $0.84[0.72-0.99], \mathrm{p}=0.040)$ after adjusting for baseline Framingham risk score, LVH, treatment, and eGFR (Table 2). These associations were also significant for the unadjusted analysis for cardiovascular death, and for the primary composite endpoint, stroke, and cardiovascular death when adjusted for baseline Framingham risk score and LVH (Table 2).

\section{Discussion}

In the present investigation of high-risk patients with ISH and LVH, we found that lower hemoglobin during follow-up was significantly related to a higher rate of the LIFE primary composite endpoint of cardiovascular death, fatal and non-fatal stroke, and fatal and non-fatal myocardial infarction, after adjustment for Framingham risk score and LVH. Lower follow-up hemoglobin was of borderline significance when treatment and eGFR were also added to the model. Lower follow-up hemoglobin was significantly related to cardiovascular death and stroke in both sets of covariate adjustments (i.e., Framingham risk and LVH with or without treatment and eGFR). When considered separately with adjustment for covariates, a 25\% lower relative risk of cardiovascular death and a $19 \%$ lower risk of stroke was detected per $\mathrm{g} / \mathrm{dL}$ higher hemoglobin. The association of higher hemoglobin with fewer cardiovascular events did not show a clear threshold level in this population, nor was any U- or J-shaped relation detected. The patients treated with the losartan-based regimen had a larger decrease in hemoglobin than the patients on the atenolol-based regimen, consistent with the results of Robles et al. ${ }^{17}$. The statistical significance of benefits associated with losartan-based therapy previously reported in 
the LIFE ISH substudy ${ }^{12}$ was sustained or even modestly enhanced in the present analyses that also took time-varying hemoglobin into account. In addition, the present results in the subset of the LIFE population with ISH confirm the finding of the association of low hemoglobin with several endpoints, including all-cause mortality, in a preliminary analysis of the entire LIFE study population. ${ }^{18}$

The World Health Organization defines anemia as hemoglobin concentration $<13.0 \mathrm{~g} / \mathrm{dL}$ for men and post-menopausal women, and $<12.0 \mathrm{~g} / \mathrm{dL}$ for pre-menopausal women. ${ }^{19}$ Among otherwise healthy individuals, anemia is well tolerated because of compensating mechanisms, and optimal hemoglobin level is a matter of debate. Still, in the Atherosclerosis Risk in Communities (ARIC) study, ${ }^{5}$ a clear relation between risk for cardiovascular disease and lower hemoglobin levels in both women and men was revealed. In chronic kidney disease, however, no benefit of complete correction of anemia has been seen. ${ }^{20-21}$

Some limitations to these analyses need to be mentioned. The LIFE study population was of older age and mainly white ethnicity. LIFE enrolled patients with hypertension and ECGLVH, a population at high risk for cardiovascular events. Analyses of patients with ISH in LIFE are subgroup analyses of the LIFE population, although the ISH group was selected a priori as being of special interest.

In conclusion, while lower hemoglobin at baseline or fall in hemoglobin over time are associated with higher probability of outcomes, this was attenuated by treatment with losartan in the LIFE study. This observation does not suggest that attempting to increase hemoglobin in this cohort is warranted. This analysis confirms previous studies that describe lower hemoglobin, even at the low normal range, as an adverse prognostic sign. 
1. Fossum E, Hoieggen A, Moan A, Nordby G, Velund TL, Kjeldsen SE. Whole blood viscosity, blood pressure and cardiovascular risk factors in healthy blood donors. Blood Press 1997;6:161-165.

2. Folkow B. The fourth Volhard lecture: cardiovascular structural adaptation; its role in the initiation and maintenance of primary hypertension. Clin Sci Mol Med Suppl $1978 ; 4: 3 s-22 s$.

3. Erikssen G, Thaulow E, Sandvik L, Stormorken H, Erikssen J. Haematocrit: a predictor of cardiovascular mortality? J Intern Med 1993;234:493-499.

4. Devereux RB, Drayer JI, Chien S, Pickering TG, Letcher RL, DeYoung JL, Sealey JE, Laragh JH. Whole blood viscosity as a determinant of cardiac hypertrophy in systemic hypertension. Am J Cardiol 1984;54:592-595.

5. Sarnak MJ, Tighiouart H, Manjunath G, MacLeod B, Griffith J, Salem D, Levey AS. Anemia as a risk factor for cardiovascular disease in The Atherosclerosis Risk in Communities (ARIC) study. J Am Coll Cardiol 2002;40:27-33.

6. Ezekowitz JA, McAlister FA, Armstrong PW. Anemia is common in heart failure and is associated with poor outcomes: insights from a cohort of 12065 patients with newonset heart failure. Circulation 2003;107:223-225.

7. Dahlöf B, Devereux RB, Kjeldsen SE, Julius S, Beevers G, de Faire U, Fyhrquist F, Ibsen H, Kristiansson K, Lederballe-Pedersen O, Lindholm LH, Nieminen MS, Omvik P, Oparil S, Wedel H; LIFE Study Group. Cardiovascular morbidity and mortality in the Losartan Intervention For Endpoint reduction in hypertension study (LIFE): a randomised trial against atenolol. Lancet 2002;359:995-1003. 
8. Dahlöf B, Devereux R, de Faire U, Fyhrquist F, Hedner T, Ibsen H, Julius S, Kjeldsen S, Kristianson K, Lederballe-Pedersen O, Lindholm LH, Nieminen MS, Omvik P, Oparil S, Wedel H. The Losartan Intervention For Endpoint reduction (LIFE) in Hypertension study: rationale, design, and methods. The LIFE Study Group. Am J Hypertens 1997; 10(7 Pt 1):705-713.

9. Dahlöf B, Devereux RB, Julius S, Kjeldsen SE, Beevers G, de Faire U, Fyhrquist F, Hedner T, Ibsen H, Kristianson K, Lederballe-Pedersen O, Lindholm LH, Nieminen MS, Omvik P, Oparil S, Wedel H. Characteristics of 9194 patients with left ventricular hypertrophy: the LIFE study. Losartan Intervention For Endpoint Reduction in Hypertension. Hypertension 1998; 32:989-997.

10. Lindholm LH, Ibsen H, Dahlöf B, Devereux RB, Beevers G, de Faire U, Fyhrquist F, Julius S, Kjeldsen SE, Kristiansson K, Lederballe-Pedersen O, Nieminen MS, Omvik P, Oparil S, Wedel H, Aurup P, Edelman J, Snapinn S; LIFE Study Group. Cardiovascular morbidity and mortality in patients with diabetes in the Losartan Intervention For Endpoint reduction in hypertension study (LIFE): a randomised trial against atenolol. Lancet 2002;359:1004-1010.

11. Kjeldsen SE, Dahlöf B, Devereux RB, Julius S, de Faire U, Fyhrquist F, Ibsen H, Kristianson K, Lederballe-Pedersen O, Lindholm LH, Nieminen MS, Omvik P, Oparil S, Wedel H. Lowering of blood pressure and predictors of response in patients with left ventricular hypertrophy: the LIFE study. Losartan Intervention For Endpoint. Am J Hypertens 2000;13:899-906.

12. Kjeldsen SE, Dahlöf B, Devereux RB, Julius S, Aurup P, Edelman J, Beevers G, de Faire U, Fyhrquist F, Ibsen H, Kristianson K, Lederballe-Pedersen O, Lindholm LH, 
Nieminen MS, Omvik P, Oparil S, Snapinn S, Wedel H; LIFE (Losartan Intervention for Endpoint Reduction) Study Group. Effects of losartan on cardiovascular morbidity and mortality in patients with isolated systolic hypertension and left ventricular hypertrophy: a Losartan Intervention for Endpoint Reduction (LIFE) substudy. JAMA 2002;288:1491-1498.

13. Molloy TJ, Okin PM, Devereux RB, Kligfield P. Electrocardiographic detection of left ventricular hypertrophy by the simple QRS voltage-duration product. $J$ Am Coll Cardiol 1992;20:1180-1186.

14. Okin PM, Roman MJ, Devereux RB, Kligfield P. Electrocardiographic identification of increased left ventricular mass by simple voltage-duration products. $J$ Am Coll Cardiol 1995;25:417-423.

15. Sokolow M, Lyon TP. The ventricular complex in left ventricular hypertrophy as obtained by unipolar precordial and limb leads. 1949. Ann Noninvasive Electrocardiol 2001;6:343-368.

16. Levey AS, Bosch JP, Lewis JB, Greene T, Rogers N, Roth D. A more accurate method to estimate glomerular filtration rate from serum creatinine: a new prediction equation. Modification of Diet in Renal Disease Study Group. Ann Intern Med 1999;130:461-470.

17. Robles NR, Angulo E, Grois J, Barquero A. Comparative effects of fosinopril and irbesartan on hematopoiesis in essential hypertensives. Ren Fail 2004;26:399-404.

18. Olsen MH, Wachtell K, Beevers G, Dahlöf B, Devereux RB, de Faire U, Fyhrquist F, Ibsen H, Kjeldsen SE, Lederballe-Pedersen O, Lindholm LH, Nieminen MS, Omvik P, Oparil S, Wedel H. High hemoglobin was associated with cardiovascular events, 
low hemoglobin with all-cause mortality, and large fall in hemoglobin with both in patients with hypertension and left ventricular hypertrophy: The LIFE study. $J \mathrm{Am}$ Coll Cardiol 2006;47:361A (abstract).

19. Nutritional anaemias. Report of a WHO scientific group. World Health Organ Tech Rep Ser 1968;405:5-37.

20. Drueke TB, Locatelli F, Clyne N, Eckardt KU, Macdougall IC, Tsakiris D, Burger HU, Scherhag A; CREATE Investigators. Normalization of hemoglobin level in patients with chronic kidney disease and anemia. N Engl J Med 2006;355:2071-2084.

21. Singh AK, Szczech L, Tang KL, Barnhart H, Sapp S, Wolfson M, Reddan D; CHOIR Investigators. Correction of anemia with epoetin alfa in chronic kidney disease. $N$ Engl J Med 2006;16:2085-2098. 
Figure 1. Summary of hemoglobin level at different time points by treatment.

Figure 2. Results obtained from Cox proportional hazard model with baseline hemoglobin quintiles and with adjustment for baseline Framingham risk score, treatment, and estimated glomerular filtration rate. Comparison is with the lowest quintile of hemoglobin ( $12.9 \mathrm{~g} / \mathrm{dL})$.

$$
\mathrm{CI}=\text { confidence interval }
$$


Table 1

Baseline characteristics of LIFE patients with isolated systolic hypertension ${ }^{12}$

\begin{tabular}{|c|c|c|c|}
\hline Variable & $\begin{array}{l}\text { Losartan } \\
(\mathrm{n}=660)\end{array}$ & $\begin{array}{l}\text { Atenolol } \\
(\mathrm{n}=666)\end{array}$ & $\begin{array}{c}\text { All } \\
(\mathrm{n}=1326)\end{array}$ \\
\hline Age (years) & $70.2(6.4)$ & $70.4(6.3)$ & $70.3(6.3)$ \\
\hline Female & $388(58.8 \%)$ & $408(61.3 \%)$ & $796(60.0 \%)$ \\
\hline \multicolumn{4}{|l|}{ Ethnic origin } \\
\hline White & $606(91.8 \%)$ & $617(92.6 \%)$ & $1223(92.2 \%)$ \\
\hline Black & $44(6.7 \%)$ & $37(5.6 \%)$ & $81(6.1 \%)$ \\
\hline Hispanic & $5(0.8 \%)$ & $9(1.4 \%)$ & $14(1.1 \%)$ \\
\hline Asian & $4(0.6 \%)$ & $2(0.3 \%)$ & $6(0.5 \%)$ \\
\hline Other & $1(0.2 \%)$ & $1(0.2 \%)$ & $2(0.2 \%)$ \\
\hline Blood pressure (mm Hg) & $174.2 / 83.0(10.7 / 5.4)$ & $174.5 / 82.3(11.0 / 6.2)$ & $174.4 / 82.6(10.9 / 5.8)$ \\
\hline Heart rate (beats/min) & $71.5(10.3)$ & $71.5(11.3)$ & $71.5(10.8)$ \\
\hline Body mass index $\left(\mathrm{kg} / \mathrm{m}^{2}\right)$ & $27.2(4.6)$ & $27.7(5.2)$ & $27.5(4.9)$ \\
\hline $\begin{array}{l}\text { Cornell voltage-duration product } \\
(\mathrm{mm} \bullet \mathrm{msec})\end{array}$ & $2771.9(1077.8)$ & $2820.2(1157.0)$ & $2795.6(1118.1)$ \\
\hline Sokolow-Lyon (mm) & $30.8(10.5)$ & $31.4(10.6)$ & $31.1(10.6)$ \\
\hline Framingham risk score & $0.230(0.103)$ & $0.238(0.098)$ & $0.232(0.101)$ \\
\hline Current smokers & $95(14.4 \%)$ & $102(15.4 \%)$ & $197(14.9 \%)$ \\
\hline Previously untreated & $233(35.3 \%)$ & $211(31.7 \%)$ & $444(33.5 \%)$ \\
\hline Coronary heart disease & $158(23.9 \%)$ & $140(21.0 \%)$ & $298(22.5 \%)$ \\
\hline Cerebrovascular disease & $70(10.6 \%)$ & $86(12.9 \%)$ & $156(11.8 \%)$ \\
\hline Peripheral vascular disease & $57(8.6 \%)$ & $55(8.3 \%)$ & $112(8.4 \%)$ \\
\hline Atrial fibrillation & $28(4.2 \%)$ & $39(5.9 \%)$ & $67(5.1 \%)$ \\
\hline Diabetes & $103(15.6 \%)$ & $131(19.7 \%)$ & $234(17.6 \%)$ \\
\hline Hemoglobin (gm/dL) & $13.86(1.27)$ & $13.90(1.21)$ & $13.88(1.24)$ \\
\hline Serum creatinine (micromol/L) & $89.13(22.27)$ & $87.50(19.91)$ & $88.31(21.12)$ \\
\hline eGFR (mL/min/1.73 m²) & $70.21(16.09)$ & $70.36(15.57)$ & $70.29(15.82)$ \\
\hline
\end{tabular}

eGFR = estimated glomerular filtration rate 
Table 2

Effect of time-varying hemoglobin on cardiovascular endpoints

$\begin{array}{lccc} & & \text { Adjusted } & \text { Adjusted } \\ & \text { Unadjusted } & \text { for baseline FRS }+ \text { LVH } & \text { for baseline FRS + LVH+ treatment }+ \\ & \text { HR }(95 \% \mathrm{CI}) & \text { HR }(95 \% \mathrm{CI}) & \begin{array}{c}\text { eGFR } \\ \text { HR }(95 \% \mathrm{CI})\end{array} \\ \text { Primary composite endpoint } & 0.95(0.84-1.07) & 0.89(0.79-1.00) & 0.90(0.80,1.01) \\ & \mathrm{p}=0.371 & \mathrm{p}=0.046 & \mathrm{p}=0.077 \\ \text { Cardiovasculardeath } & 0.83(0.70-0.99) & 0.79(0.67-0.93) & 0.75(0.63-0.90) \\ & \mathrm{p}=0.034 & \mathrm{p}=0.005 & \mathrm{p}=0.001 \\ \text { Stroke } & 0.87(0.74-1.02) & 0.83(0.71-0.97) & 0.84(0.72-0.99) \\ & \mathrm{p}=0.093 & \mathrm{p}=0.020 & \mathrm{p}=0.040 \\ \text { Myocardial infarction } & 1.08(0.89-1.31) & 1.02(0.84-1.24) & 1.02(0.83-1.25) \\ & \mathrm{p}=0.437 & \mathrm{p}=0.831 & \mathrm{p}=0.854\end{array}$

$\mathrm{CI}=$ confidence interval; eGFR = estimated glomerular filtration rate; FRS = Framingham risk score; HR = hazard ratio per g/dL of hemoglobin. 
Figure 1. Summary of hemoglobin level $($ mean $\pm \mathrm{SD})$ at different time points by treatment

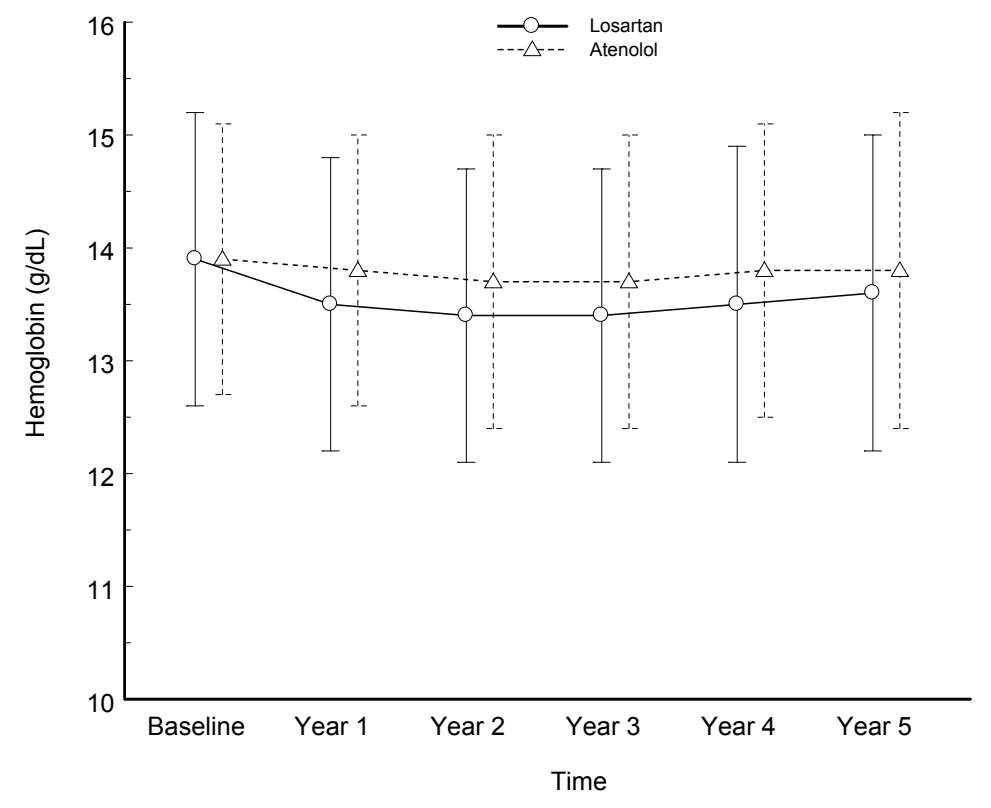


Figure 2. Results obtained from Cox proportional hazard model with baseline hemoglobin quintiles and with adjustment for baseline Framingham risk score, treatment, and estimated glomerular filtration rate. Comparison is with the lowest quintile of hemoglobin ( $12.9 \mathrm{~g} / \mathrm{dL})$.

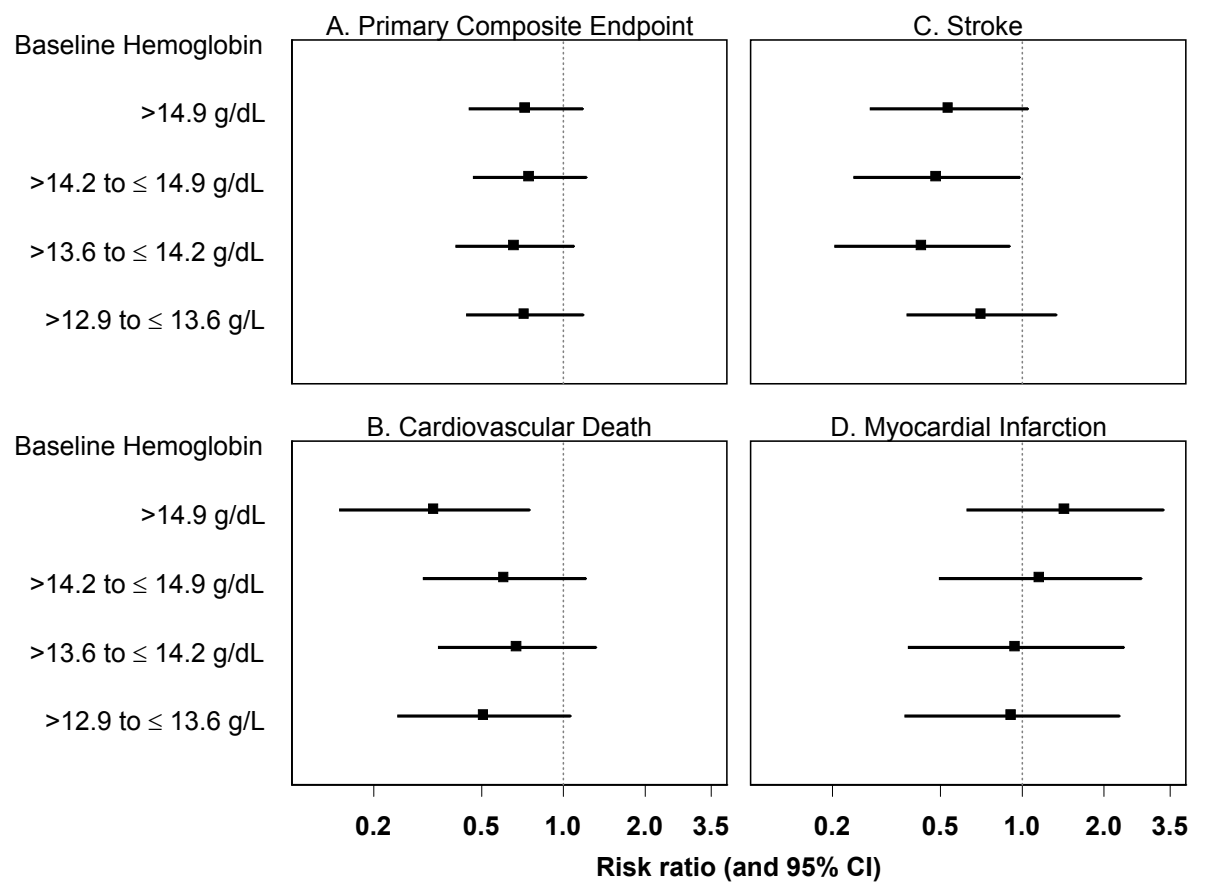

